\title{
Comanagement at the Fringes: Examining Stakeholder Perspectives at Macassar Dunes, Cape Town, South Africa-at the Intersection of High Biodiversity, Urban Poverty, and Inequality
}

\author{
M. Graham $^{1}$ and $\underline{\text { H. Ernstson }}^{2,3}$
}

\begin{abstract}
Theoretically, co-management provides a fruitful way to engage local residents in efforts to conserve and manage particular spaces of ecological value. However, natural resource management, and biodiversity conservation in particular, are faced with novel sets of complexities in the rapidly urbanizing areas of Cape Town, South Africa, and in the nexus between an apartheid past, informal settlements, remnant biodiversity patches, and urban poverty. Departing from such a dynamic social and ecological context, this article first provides an historical account of the decade-long comanagement process at Macassar Dunes, and then considers, through stakeholder perceptions, what are the successes and failures of the contested process. We find that comanagement at Macassar Dunes faces serious legitimacy, trust, and commitment issues, but also that stakeholders find common ground on education and awareness-raising activities. In conclusion we argue that the knowledge generated from case studies like this is useful in challenging and rethinking natural resource management theory generally, but specifically it is useful for the growing cities of the Global South. More case studies and a deeper engagement are needed with geographical theories on the "urban fringe" as "possibility space", to help build a firm empirical base for theorizing comanagement "at the fringes", i.e., at the intersection of poverty, socioeconomic inequality, and high biodiversity and ecological values.
\end{abstract}

Key Words: Cape Town, South Africa; comanagement; informal settlement; Macassar Dunes; remnant biodiversity; stakeholder perspectives; urban comanagement; urban ecology; urban poverty

\section{INTRODUCTION}

A purported and oft-cited phenomenon is that the world is witnessing unsurpassed urbanization. The United Nations, for example, estimates over 6 billion people are projected to live in cities by 2050 (United Nations Department of Economic and Social Affairs 2012). Around half of those 6 billion people are predicted to inhabit urban slum areas in the less developed regions of the world (http://www.unhabitat.org/content.asp?t ypeid=19\&catid=10\&cid=928), and in Africa alone the urban population is likely to treble, with some 850 million new urban dwellers forecast to 2050 (United Nations Department of Economic and Social Affairs 2012). As cities expand in population, many cities increasingly also extend spatially into areas of ecological importance, i.e., into the geographic "city fringe". In cities of the Global South in particular, the urban poor have great difficulties in accessing secure tenure and adequate housing options. As a consequence, the city fringe becomes the site of growing informal settlements that lack access to formalized services and amenities like water, sanitation, waste disposal, and electricity. Such "extra-legal" property regimes are informed by a suite of complex historical and contemporary planning and access issues, often with bases in brutal and segregational colonial pasts and persistent legacies of inequality (see Kingwill et al. 2006; Watson 2009). These issues ensue in competing and conflicting claims to land uses at the urban fringe, and also impact the dynamics of local ecosystems. As such, we understand that Natural Resource
Management, as theory and practice, encounters novel situations at the urban fringes of the Global South. To contribute to a "rethinking" of natural resource management theory such that it might be sensitive to such situations, places, and processes calls for the examination of case studies in specific urban fringe areas of the Global South.

This article combines natural resource management theory with cultural geography, and uses a qualitative case-study approach to examine some of the challenges and conflicts of natural resource management in the context of an urban protected area - i.e., Macassar Dunes, which is located on the geographical fringe of Cape Town, South Africa. It focuses on comanagement arrangements at Macassar Dunes under the auspices of the Macassar Dunes Co-management Association (MDCA) to consider comanagement processes at the intersection of vast, rapid, and highly dense informal settlement; a remnant, small-scale, highly biodiverse protected area; and, the urban poverty realities and development desires of informal settlers and township residents in the township areas located on Cape Town's geographic city fringes. In particular we use this paper to focus on two questions. First, in the Results section we consider: What are stakeholders' perceptions of the bridges and barriers to comanagement at Macassar Dunes? Second, in the Discussion we consider: What does comanagement literature tell us about these bridges and barriers in the context of urban protected areas at "the fringes"?

\footnotetext{
${ }^{1}$ Department of Systems Ecology, Stockholm University, ${ }^{2}$ African Centre for Cities, University of Cape Town, ${ }^{3}$ Stockholm Resilience Centre, Stockholm University
} 


\section{BACKGROUND}

The comanagement concept in contemporary natural resource management is positioned within an important opportunity space, lying between having "substantial promise" in addressing conflict in natural resource management, and actually serving as a "source of conflict" (Castro and Nielson 2001). As such, we posit consideration of comanagement as a method and a tool for managing the socio-cultural and ecological diversity in urban protected areas is an important field of inquiry. In 1997 Berkes recognized the imperative for examining stakeholder understandings within comanagement arrangements. In his suggested research strategy to build comanagement theory based on the examination of real-world comanagement processes and arrangements, he included the need to focus on the reasons for successes and failures of these. A decade and a half later, mounting critique of the comanagement concept suggests Berkes' strategy remains pertinent. Adams et al. (2003) note that addressing conflict in natural resource management requires consideration of the perceptions of stakeholders, and the differing ways by which management problems are understood. We heretofore draw on Berkes (1997) and Adams et al. (2003) in this paper in our analysis of stakeholder perceptions of the bridges and barriers to comanagement at Macassar Dunes. By examining the experiences and perceptions of persons involved in the MDCA's Management Committee, the peak decision-making body of the MDCA, we strive to give some voice to and analyze perceptions of the "successes" and "failures" of the comanagement process to date.

As a case study into the challenges and contestedness of urban protected area comanagement, Macassar Dunes is highly appropriate because it represents a relatively long-term comanagement process. This allows participants considerable time for reflection on their experiences and expectations of the arrangements. Further, comanagement arrangements and analyses commonly focus on indigenous or "local" peoples deemed to have long-term associations with the comanaged site or resources (see, for example, Castro and Nielson 2001, Spaeder and Feit 2005, Izurieta et al. 2011, and BorriniFeyerabend et al. 2001, amongst many others). With the inclusion of informal settlers and township residents as legitimate and central actors in the comanagement process, Macassar Dunes represents a less developed field of comanagement practice and theory. We believe this condition provides an important entry point for consideration of who has the right to define and "speak for" common pool resources in contested urban spaces. While only briefly contextualized here, in a future paper we will also explore the particular nexus of historical, social, cultural, environmental, and geographical contexts through which the comanagement arrangements at Macassar Dunes are enacted.

In 2006, Ferketic et al. (2010:1170) undertook a study at Macassar Dunes to "assess the potential of a conservation justice management agreement", which presents an important starting point for considering the understandings that individual community members and conservationists have of the trade-offs between predefined conservation and development issues. Our study focuses on the existing comanagement process and participants at Macassar Dunes (as of December 2009); in so doing we recognize the contested and processual nature of comanagement, and the significant legitimacy issues this arrangement faces, given some participants feel the process is "dead", while others feel it is still "alive". Further, our qualitative approach enables an appreciation of the emotions, perceptions, and conflicts engendered by and through these arrangements. Together with the approach of Ferketic et al. (2010), our studies provide valuable complementary understandings on perceptions of comanagement from both "inside" and "outside" the existing process. To attend to an understanding of the existing arrangements as at December 2009, we present a description of the case study area, including an interpretative historical description of the comanagement process.

\section{THEORY}

\section{Comanagment and urban protected areas}

This study's point of departure is the notion that cities generally encapsulate much social, cultural, and environmental diversity and economic differentiation. This situation leads to great challenges and often intense struggles over how to best use urban space, and which kinds of values, needs, and development trajectories should inform such uses (Harvey 1996; Ernstson et al. 2010; Cook and Swyngedouw 2012). Focusing on the context of the management of urban nature, contestation can occur over fundamental issues relating to who has the right to "speak" for the places and resources being managed; what values and beliefs are reflected in management paradigms and approaches; and who benefits in what ways from management outcomes (see, for example, Ernstson and Sörlin 2009).

In natural resource management, a conventional management strategy to address issues of diversity, complexity, and contestation is the concept of "comanagement". Herein we review the literature on comanagement theory and critique, and seek to position comanagement within the context of urban protected areas. This positioning is important because there is increased recognition of the contribution of urban green spaces - such as forests, parks, wetlands, and protected areas- to human health and wellbeing, and in the provision of ecosystem services in cities (Bolund and Hunhammar 1999; Alcamo et al. 2003; Niemelä et al. 2011). However, urban protected areas face challenges and impacts resulting from processes such as urban sprawl and development, urban agglomeration, informal settlement, and tourism development (Trzyna 2007). Using examples from around the world, including some from Cape Town, Trzyna (2007) identified that these challenges 
and impacts include habitat fragmentation, effects on water quantity and quality, air, solid waste, and noise pollution; spread of exotic, invasive species; human-wildlife conflicts; natural, accidental, or intentional fire; and criminal activity such as vandalism, theft, poaching, arson, mugging, and murder (see also Rebelo et al. 2011).

Comanagement seeks to bring together resource users in shared stakeholder management regimes. Such arrangements theoretically provide potentiality to "democratise decisionmaking, foster conflict-resolution, and encourage stakeholder participation" (Armitage et al. 2007). The premise is that comanagement is not just about managing resources but is also fundamentally about managing relationships (Goetze 2005). By working to incorporate a diversity of stakeholders, comanagement aims to provide opportunity space for building trust and linkages between interested parties. In so doing, the inclusionary practices are purported to increase the legitimacy of decision-making processes and, furthermore, engender better resource management by incorporating processes of social learning and knowledge integration (see Armitage et al. 2007; Berkes 2009). Analysis on the actual implementation of comanagement arrangements is largely focused on nonurban settings such as large-scale protected areas, fisheries, and forests. Urban settings are currently underrepresented in the literature, perhaps demonstrating a paucity of existing arrangements. Nevertheless, Barthel et al. (2005) recently suggested the imperative for urban comanagement arrangements to engage and enhance the contributions of local stewardship associations to the maintenance of urban ecosystem services and biodiversity.

Our focus on comanagement at the urban "fringes" of the Global South requires an understanding of how marginalized groups and peoples have interacted with comanagement processes and practice. Attendance to marginality in comanagement is highly pertinent given the potentiality of "deep-colonizing" (Rose 1999) processes embedded in resource management practices and institutions. Howitt and Suchet-Pearson (2006) note that through such deep-colonizing practices and institutions, including comanagement, the "concepts and practices of separation, superiority, intervention, control and management are often reimposed" (page 325), resulting in serious implications for indigenous and other marginalized peoples. Drawing on experiences from nonurban settings provides an important entry point to understanding issues of marginality in comanagement.

Castro and Nielson (2001) indicate that whilst comanagement arrangements involving indigenous peoples offer "substantial promise" in addressing conflict in natural resource management, experience has shown that such arrangements can enhance and/or create conflict, and contribute to greater marginality of already marginalized peoples. The International Union for the Conservation of Nature (IUCN), as a high-level and traditional proponent of comanagement (World Parks Congress 2003), soberly suggests: “[w]hen successful, [comanagement] spells out the peaceful and intelligent ways by which communities and other actors overcome environmental challenges, take best advantage of nature's gifts, and share those in fairness and solidarity. When it fails, it ushers conflicts, human misery and environmental damages" (http://www.iucn.org/about/union/commissions/ceesp/ sharing power/about/the inspiration/). In a more focused critique based on the Southern African experience, Kepe (2008:312) states that the widespread implementation of comanagement regimes has "represented a camouflage for the continuation of state hegemony regarding the protected area or national park idea in post-apartheid South Africa". Cock and Fig (1999, in Magome and Murombedzi 2003) note also that comanagement has "seldom succeeded" in the South African context. They view ensuing conflicts erupting over the "pure" conservation basis of management as effectively constricting the potential of local communities to derive benefit and income from their lands (Magome and Murombedzi 2003).

In moving towards an understanding of comanagement theory within the context of urban protected areas at the urban fringes of cities of the Global South, we here focus on three central aspects of comanagement theory: (1) the impetus for and context of comanagement implementation, (2) perceptions of legitimacy of comanagement arrangements, and (3) the notion of comanagement as process.

Firstly, the impetus for and context of comanagement implementation are seminal considerations. Indeed, Chuenpagdee and Jentoft (2007) focus on the preimplementation stage as a fundamental period of the comanagement arrangements, during which the actions taken and contextual factors can have implications for the future success of the arrangements.

Secondly, Kofinas (2005) has noted that it is through gaining the perception of legitimacy that stakeholder consensus can be reached and transformed into action within the group. This perception is nevertheless bound to be dynamic, and therefore requires cultivation in order to persist (Kofinas 2005). Kofinas (2005) further understands legitimacy in comanagement arrangements as encompassing three dimensions of stakeholder perceptions: (1) the legitimacy of the arrangements themselves, (2) the legitimacy of the different types of knowledge that underpin comanagement decisions and decision-making processes, and (3) the legitimacy of the comanagement participants as being inclusive of both individuals and organ is at ions.

Finally, the conception of comanagement as process, reflects the understanding that building relationships for shared management is time-intensive, and involves extensive deliberation, negotiation, and the evolution of agreements 
(Berkes 2009). Indeed, Armitage et al. (2009) have noted that some arrangements may take over a decade to "mature" into effective governance arrangements. Importantly, recognition of comanagement as processual highlights that power-sharing comes as a result of the process, rather than because it is an expected outcome (Carlsson and Berkes 2005).

\section{CASE STUDY AREA: SOCIAL, ECOLOGICAL, AND HISTORICAL CONTEXT}

Cape Town city is nested amidst a highly biodiverse landscape, lying as it is within the Cape Floristic Region. At the same time, developmental pressures mean Cape Town has the highest number of threatened plant species of any city in the world (http://www.capetown.gov.za/en/EnvironmentalResou rceManagement/functions/BiodivManagement/Pages/

BiodiversityNetwork.aspx; see also Rebelo et al. 2011). These ecological and social conditions have informed scientific and policy-related arguments to protect Macassar Dunes. Located to the southeast of the City Bowl ( Fig. 1), Macassar Dunes represents the last remnant of endangered strandveld vegetation along the False Bay Coast. The dunes area incorporates the Macassar Dunes Conservation Area and the adjoining Wolfgat Nature Reserve, as well as a privately owned and publicly inaccessible conservation area at the eastern end of the dunes, and several beach zones managed by the City of Cape Town at the western end (Fig. 2). The Macassar Dunes are identified within the City's Biodiversity Network as a core conservation site for the Cape Flats area (City of Cape Town 2007; and see Cilliers and Siebert 2012 regarding the Biodiversity Network). The Wolfgat Nature Reserve boasts 178 plant species, including a protected stand of endangered White Milkwood trees (Sideroxlyon inerme) (Cape Flats Nature 2010). A short observational study from 2006 concluded that the dunes support a varied animal population, with 27 bird, 14 mammal, and 6 reptile species recorded, and a further 32 species suspected (Langley 2006). The coast off the dunes provides habitat for marine life such as fish, seals, great white sharks, and dolphins, and for the seasonal migration of several species of whale (Bodenstein and Rippon 2001).

However, Macassar Dunes also lies on the doorstep of one of South Africa's largest "township" areas, Khayelitsha, which is home to an estimated 450,000 to 1 million people (Skuse and Cousins 2007), consisting of both established long-term residents and newer informal housing (shacks and backyard dwellings) comprising more than two-thirds of all households, and at $75 \%$ under 35 years of age, the population is overwhelmingly young (Base of the Pyramid Learning LabSouth Africa 2011). In effect, Khayelitsha faces "the same issues as hundreds of other poor settlements in South Africa: [p]overty, inadequate housing, lack of access to sanitation and running water, lack of access to energy, high unemployment and crime" (Base of the Pyramid Learning Lab-South Africa 2011:2). eNkanini is one of Khayelitsha's large informal settlement areas. It houses an estimated 16,000 residents in shack dwellings, and is separated from Macassar Dunes only by the primary coastal access road, Baden Powell Drive (see Fig. 2). eNkanini sprang to existence in 2003 when settlers initiated a land claim movement by "invading" this open space (see Skuse and Cousins 2007). The Dunes also border Macassar town, which was appropriated and expanded from a small community during the apartheid era to house "Colored" residents. The Macassar community faces many similar employment, housing, services, and amenities access issues as other "previously disadvantaged communities" in Cape Town. The contemporary Macassar community is believed to have a long history of interaction and cultural ties with Macassar Dunes (Bodenstein and Rippon 2006) including historical usage stemming from agricultural practices such as stock grazing, and recreational practices such as horse riding and fishing.

Fig. 1. Location of Macassar Dunes in relation to Cape Town City Bowl (city center). (Map not to exact scale.)

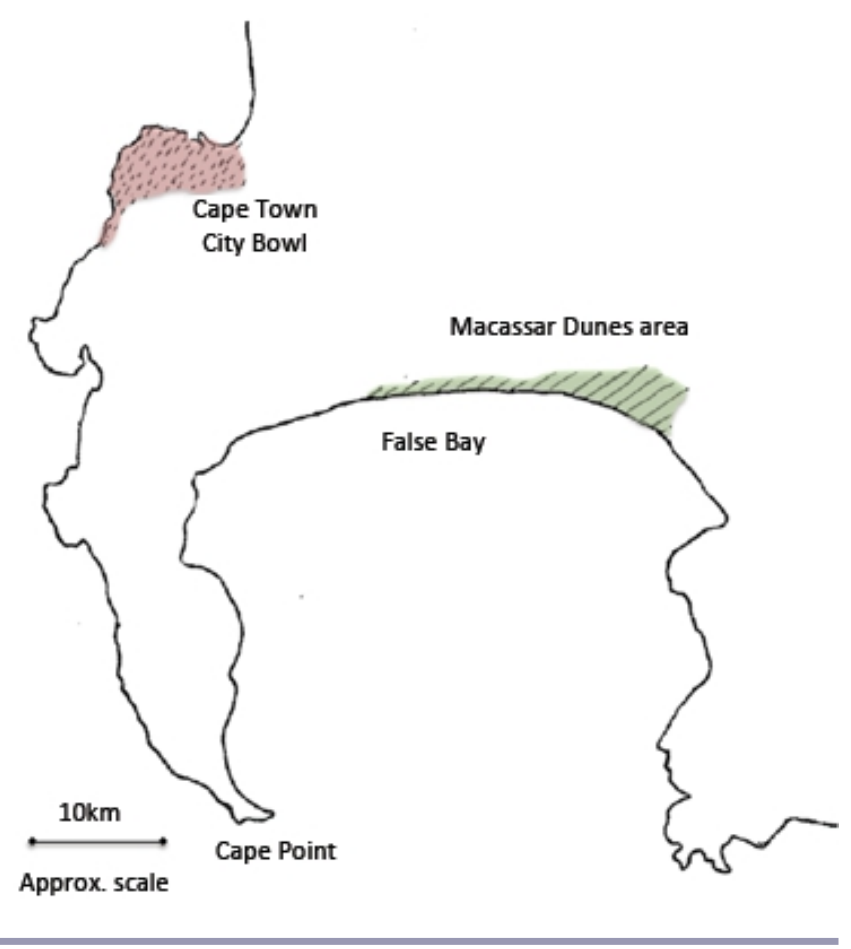

\section{Reconstructing the history of comanagement at Macassar Dunes}

Based on comanagement process documentation, field notes, and interviews during the course of this study, the history of comanagement arrangements at Macassar Dunes presents a long, disjointed, and contested process. Prior to the restructuring of Cape Town into a single municipality in 2000, the then Tygerberg Local Government area was responsible 
Fig. 2. Macassar Dunes and surrounding area, showing the proximity of the Macassar and Khayelitsha townships, and eNkanini informal settlement. Enkanini is separated from the dunes by the coastal access road, which is called Baden Powell Drive. (Map not to exact scale.)

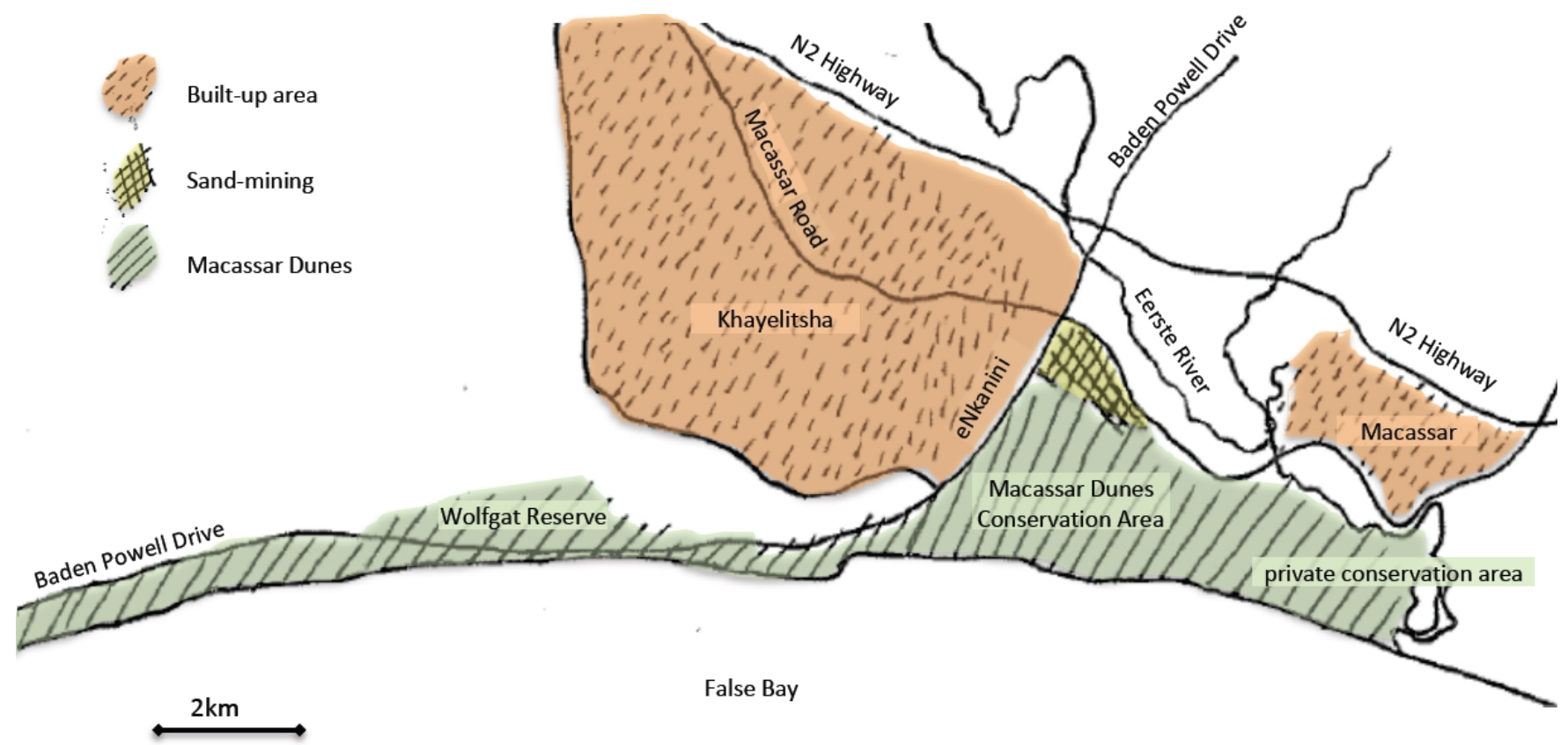

Approx. scale

for the dunes area. Because local government staff were not present on the ground at Macassar Dunes during this time, the Macassar Dunes Management Plan was devised to provide a strategic management plan for the future of the dunes area (Chittenden Nicks de Villiers 2001). It was in this Plan that the implementation of comanagement at Macassar Dunes was first suggested. In 1999 local government planning staff and university researchers perceived local communities were causing environmental degradation to the dunes through encroaching informal settlement, illegal hunting and harvesting, and misuse of the area for latrine and anti-social purposes. Legal and illegal sand-mining operations in the dunes were also perceived as being undertaken irresponsibly, and with little regard for the environmental values of the area. Drawing on the Macassar Dunes Management Plan, these perceived threats served as a catalyst for instigating comanagement arrangements, with the aims of reducing environmental degradation through increasing local community awareness of the dunes.

A trial comanagement process began in 2000, involving the City of Cape Town's strategic planning staff (hereafter City of Cape Town planning), and a specialized environmental unit at the University of Cape Town as the implementing organization. Intensive community engagement processes and a series of environmental education and comanagement stakeholder training workshops were conducted over 2 years by the University of Cape Town, and involving City of Cape Town planning staff; Macassar and Khayelitsha community members; and other business, industry, and government representatives. These resulted in a draft vision for the reserve area:

... to acquire conservation status for the entire area allowing appropriate and compatible activities within a co-management framework. We envisage the sustainable use of local resources by local people as well as the sustainable use of the area for educational purposes, tourism and recreation. We support activities which will directly benefit local users and communities through job creation and skills development.

(University of Cape Town 2001)

Several project plans were developed for the western portion of the Conservation Area only: (1) construction of a set of walking trails to facilitate dune access; (2) construction of an environmental education center adjacent to the dunes; and, (3) training of Macassar and Khayelitsha community members in removal of alien vegetation and in visitor field-guide skills (Bodenstein and Rippon 2006). 
Table 1. The six stakeholder groupings identified during the course of the interviews.

\begin{tabular}{lll}
\hline \hline Stakeholder grouping & $\begin{array}{l}\text { In-text } \\
\text { reference }\end{array}$ & History and interaction in MDCA \\
\hline University of Cape Town staff & - & $\begin{array}{l}\text { Inter- } \\
\text { viewees } \\
\text { (no.) }\end{array}$ \\
\hline & $\begin{array}{l}\text { The University of Cape Town was partially responsible for instituting the } \\
\text { comanagement process in 1999, and has since been a long-term comanagement } \\
\text { partner, and is responsible for administering MDCA funds from donor organizations. }\end{array}$
\end{tabular}

City of Cape Town conservation staff (on-ground and management)

City of Cape Town strategic planning staff

Cape Flats Nature staff

Members of the Macassar
community

Members of the Khayelitsha community, including residents of eNkanini informal settlement
City of Cape

Town conservation

City of Cape Town planning
City of Cape Town conservation staff have been involved in comanagement arrangements since 2004 when formal on-the-ground management of Macassar Dunes was instituted.
City of Cape Town Planning authorities were partially responsible for instituting comanagement arrangements, and contracted the University of Cape Town to undertake the pilot comanagement process in 1999. Planning authority staff were involved in comanagement until around 2006, when new City of Cape Town administrative borders were instituted. Essentially, conservation staff replaced planning staff representation on MDCA.

A government/civil society partnership to support "people-centered" biodiversity conservation. Cape Flats Nature has been involved in the comanagement arrangements since 2004, in partnership with the City of Cape Town Conservation.

Macassar

Both Macassar and Khayelitsha communities have been target communities of the comanagement process since its inception in 1999. Khayelitsha
members

eNkanini residents have played a crucial role in the comanagement process since the "creation" of eNkanini informal settlement in 2004, because their land claim action sparked a revitalization of collaborative efforts at Macassar Dunes. However, formal interaction of eNkanini residents with the MDCA Management Committee has been only relatively recent.

Under apartheid, Macassar residents were classified as "Coloured", whilst Khayelitsha (and eNkanini) residents are predominantly recognized as "African" or "Black". These classifications, whilst problematic and complex, are still very present in South African discourse, and residents from these areas are still widely referred to in such terms by the comanagement partners. Nonwhite South African communities are also commonly referred to as "previously disadvantaged", referring to apartheid and historical legacies of inequality and oppression.
In 2003 this collaboration legally registered as the Macassar Dunes Co-management Association (MDCA), with a constitution outlining the rules for engagement and decisionmaking. MDCA is to consist of individuals and representatives of user and interest groups interested in the management of the Macassar Dunes. Included are individuals from local communities and community structures, and from activity groups such as wood collectors, traditional healers, fishermen, and recreationists. It also includes City of Cape Town employees, as the responsible authority for the Reserve, and the University of Cape Town, as joint implementers of the initial comanagement process. The MDCA's Management Committee is to consist of six elected members as representatives of the user or interest groups of the MDCA (MDCA Constitution 2009, personal communication). City conservation staff and MDCA have also collaborated with the Cape Flats Nature project, a collaborative project established to "address the challenge of conserving fragmented natural habitats in an urban context where land is scarce and poverty is widespread" (http://www.capeflatsnature.co.za/index.php? option=com content \&view=frontpage \&Itemid=28). In 2004, the first on-the-ground conservation management staff were located on the reserve. Following the restructuring in 2000 of the City of Cape Town local government area into a single unitary administrative area (Wilkinson 2004), these conservation staff eventually replaced the City's planning staff as representatives on the MDCA. Since 2004, on-the-ground conservation staff from the City and Cape Flats Nature have been engaged in the MDCA and its Management Committee in varying capacities and to differing degrees. 


\section{Participation and process revitalizations}

For several years, the University of Cape Town's persistent attempts to generate project funding for MDCA's proposals were unsuccessful. Whilst a core Management Committee has been fairly consistently present (if not always active) over the years, the lack of project resources resulted in several lulls and process revitalizations within the larger MDCA. The land claim "invasion" movement in 2003 that resulted in the formation of the eNkanini informal settlement sparked a group of concerned conservationists into what later loosely became the first "revitalization" of the MDCA. This group was united by the desire to educate eNkanini informal settlers about the environmental degradation that would occur should the land claim movement extend across Baden Powell Drive and thus into the boundaries of the dunes area. To address this concern, several education and information campaigns were undertaken within eNkanini. This revitalization movement faded when funds were still not forthcoming to implement the MDCA's three major project proposals.

In late 2005 the University of Cape Town successfully secured a substantial ZAR4.5 million ( US\$700,000 in 2005) grant from three different funders on behalf of the MDCA for the project proposals. Since MDCA was not a financially established entity at the time, this funding was to be initially administered by the University of Cape Town as the responsible implementing organization, and progressively to be taken over by MDCA. Spurred by the University of Cape Town, the MDCA underwent a second revitalization process so as to start the preparation of scoping reports for the funded project proposals. This process proved rather fraught because many new members were instituted in the comanagement process, whilst previous members had moved on. However, after a lengthy re-examination process, scoping reports were eventually prepared, based on the same three projects, i.e., encompassing walking trails, an education center, and community training initiatives.

In early 2007 City of Cape Town conservation staff raised significant, and previously unannounced, objections to the MDCA's proposals. These were based on concerns regarding the financial and ecological management of the proposed constructed features in the Conservation Area, and the responsibility and capacity of both the MDCA and the City's conservation unit to manage these. For example, the potential negative impacts on biodiversity in the Reserve area due to the construction of man-made features and associated increased user-accessibility were a significant issue for the City. Another issue was that the land which MDCA had proposed for the siting of the environmental education center was not owned by the City of Cape Town, but by the Department of Public Works. Whilst the Department of Public Works was willing to lease the land at no cost to MDCA, this issue nonetheless raised for the City several statutory maintenance and funding issues.
These objections appear to have caused much controversy in the comanagement process. A lengthy stalemate ensued because no consensus was reached on alternative proposals, such as choosing a new site for the education center, thus causing another faltering in membership and waning interaction in the MDCA. By 2009 failure of the MDCA parties to reach agreement had resulted in much of the project funding being returned to donors once expenditure deadlines passed. However, some specific donor funds were retained. Since 2007, approaching expenditure deadlines for these funds resulted in several further MDCA revitalization attempts, for example using funds for short-term contracts to remove invasive species. In December 2009 the issue of the MDCA's project proposals was still being negotiated and debated by the MDCA partners, with no clear agreements made.

\section{METHODS}

This qualitative analysis of comanagement arrangements at Macassar Dunes is based on interviews with past and present members of the MDCA Management Committee, conducted in Cape Town from October to December 2009. Participants were selected on the basis of being long-term and/or core members of the Management Committee over time. Participants were initially identified in MDCA documents and via staff of the University of Cape Town. Further participants were identified by suggestions from other interviewees. Six stakeholder "groupings" emerged during the interview process, in what Reed et al. (2009:1973) identify as a bottomup "stakeholder led stakeholder-categorization". Interviewees representative of each grouping were sought, and in total 25 persons were interviewed. While it is not possible to calculate exactly because of the disrupted comanagement process, we believe the interviewees represent a significant proportion of key MDCA representatives over time. Table 1 shows more information on these groupings.

It should be noted that participants were not necessarily "bound" to, nor did they necessarily identify with, just one of these groupings (see Foley and Grace 2009); for example some government staff are also residents of Khayelitsha, or have township backgrounds with which they identify, but which they are not formally representative of in the comanagement arrangements. These nuances of personal and multiple identities and group affiliation demonstrate that stakeholder groupings might be simplistic when comparing perceptions across groups. Still, in focusing on the perceptions among those heavily involved in comanagement, our approach brings forth the variety of possible perceptions. Furthermore, in choosing to use open-ended questions, we encouraged a narrative mode of communication (Willig 2001 in Rogan et al. 2005), which allowed interviewees to develop their answers in a dialogue, bringing richer contextual information to support interpretation. The semistructured interviews were organized around a set of themes and interview questions 
relating to perceptions of "bridges" and "barriers" in comanagement processes. Interviews were recorded and transcribed in full, except when it was not possible during two phone interviews, during which notes were taken.

Interviewee statements were coded using ATLAS.ti software (ATLAS.ti Scientific Software Development GmbH 2009). The coding process was adapted from the non-numerical narrative analysis methodology outlined in Rogan et al. (2005). This meant first going through each interview transcript line-by-line and coding significant parts by highly descriptive codes as represented in "natural language", and reflecting emergent themes and meanings relating to personal and social experiences (see Morse 1994 and Polkinghorne 1995 in Rogan et al. 2005). Then, given these descriptive codes, efforts were made to find more general themes. This was an iterative process of going back and forth between different interviews and their first-order codes to refine and later group these codes into more general themes (see Miles and Huberman 1994; Boyatzis 1998; Gustafson 2001 in Rogan et al. 2005).

For space and comprehension purposes the themes identified are illustrated by broader narrative descriptions. However, as evident in the coding process, interviewees talked about issues in diverse ways, describing, linking, and attributing particular themes and understandings in divergent ways. Thus, the understandings of the comanagement process as expressed by interviewees did not necessarily fit neatly into only one theme, because understandings often overlap, relate to, and are contingent upon one another. While the themes provide an overview of the data material, we have chosen to intersperse our description of the themes with direct quotes. By using the voices and insights of those directly involved in comanagement, these quotes help to bring the reader closer to how social and cultural dynamics are played out in this case of comanagement at the fringe. Although the results represent a coconstruction of knowledge between interviewer/ interviewees, it should be understood that the following is an interpretation, which nonetheless is open to re-interpretation and contestation by scholars and nonscholars alike (Willig 2001 in Rogan et al. 2005).

\section{RESULTS}

Table 2 provides an overview of the broader themes that emerged from working with the interview material across all interviewees. Descriptions of these themes and selected quotes are outlined below.

\section{Bridges to successful comanagement}

All participants feel education and awareness-raising activities (Theme A1 in Table 2) have been important and successful components of the comanagement process. This refers to educating and informing local community residents —eNkanini settlers in particular_regarding the existence of the nature reserve, its vulnerability, and its ecological values. For instance, an interviewee from the Khayelitsha community explained how local people had been trained in conservation and the eNkanini community had started to value the dunes from an ecological perspective as result of environmental awareness-raising activities:

It was a successful project, we had fifteen volunteers
that we trained in the basic practice of conservation,
and communications skills and awareness, and
general information around Macassar Dunes. And,
we did go there [to eNkanini] with the manner that
probably people will kind of ignore or not support
[us], but anyway we were amazed by how the
communitywere kind of taking the initiative. We have
come up with very good results at the end of the day:
that [eNkanini] people do know they have the
Macassar Dunes Nature Reserve next to them, and
they tell us what they use it for, and what they are
doing there. And people are telling us that they take
the initiative that if someone is building their shack
beyond the [reserve] boundary they go themselves
and say'youmustnotbuildhere; this is the boundary,
you must not build over this boundary'. So they are
taking the initiative, saying these dunes are helping
us with the sanddriftwhen it is windy from the beach,
so it is protecting us from that wind that come[s]
from the beach.

Table 2. Stakeholder-perceived bridges and barriers to comanagement at Macassar Dunes, interpreted here as broad themes developed from 25 semistructured interviews.

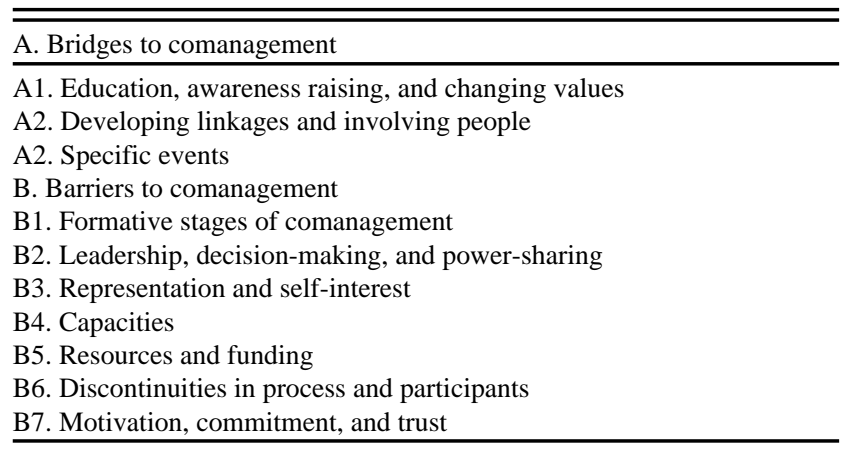

As a further example of this, a conservation staff member expressed a clear benefit from educational activities in diminishing the threat of eNkanini settlers "invading" the Reserve:

There was almost a complete halt from the invasion that was happening . . . after all this intervention of the MDCA and the different activities that [Cape Flats Nature] were doing you could literally see 
there was a halt from going up the dune ... [and] something was happening: there was a consciousness that "we are not supposed to be invading that dune".

(interview, City of Cape Town Conservation).

Still, some tension exists between residents and professional conservation managers. While residents recognized that these activities have kept the comanagement process alive during its many lulls, education could still be viewed as a "top-down" practice to impose certain ecological values from the "center" onto those living at the "fringe". The following quote demonstrates how this educational success is also perceived as being unstable and liable to political maneuverings, and how ecological awareness and stewardship are viewed by some as contingent on economic development opportunities in eNkanini:

I think the co-management to a certain extent has played a vital role, a very, very crucial role in terms of educating those communities . . . Now, the eNkanini people have very much bought into the idea of the reserve of some sort . . but they do so because there's a hope that some livelihoods will be derived from this area. Now it's a matter of how long should they wait for those activities? How long should they [wait to] see economic benefits for the area? If there are no economic benefits for the area, as a matter of protest they might deliberately invade the area. (interview, University of Cape Town).

These quotes also suggest how the loose category of "eNkanini people" has become a way to frame the value of the comanagement process as a tool to stop informal settlers from taking over the area altogether. Those living "at the fringe" are thereby also framed as threats and as unreliable stakeholders in the conservation project.

Another theme of perceived success was that the comanagement process had successfully utilized the Management Committee's community members to strengthen linkages between government staff and local communities (Theme A2). This seems to have benefitted the local government and conservation managers, who sought ways to engage the quite amorphous and dynamic "fringe" of township areas and informal settlements. Through the MDCA's members they found representatives that in turn could channel and communicate conservation issues and the work of the MDCA into community structures and forums:

[MDCA is] almost in a way like a forum, because of the representation from different [communities] and different either interested individuals or interested environmentally... So in a way we reach [out]. And generally the people that come from [the communities] . . . are people that have connections.
So in a way they do have a voice.

(interview, City of Cape Town Conservation)

These linkages also provided opportunities for community members to get involved in activities and management at the dunes. Some of these members exemplify passion for and commitment to the comanagement process:

[There are] people who have sort of passion and they just want to be involved in driving these things and getting involved in conservation . . ' Cause I believe that MDCA wouldn't be here if it wasn't for those sort of driving forces . . because you cannot sort of pinpoint and say ' $O K$, the MDCA has done this'because, you know, you don't have anything that is tangible. But you look in terms of the people that are there, and in terms of the communities, and how they relate, how they engage.

(interview, Cape Flats Nature)

A final broader theme identified in the data was specific MDCA events (Theme A3), which are perceived as highly successful and significant in that they represent relatively rare moments of successful collaboration and provide opportunity for cross-cultural exchange. The annual Heritage Day brings together diverse stakeholder groups to share and celebrate local cultural diversity and heritages:

[It] was such a great success ... and we had so many youth that day! And the diverse cultures of the surrounding areas! It was the first time there was interaction with the communities, the predominantly Black and Colored, or Métis communities . . . and there was such a close collaboration and everyone asked us 'please, make this a bigger event next year', because it was such a great success; and an enjoyable event because there was music, dance and mingling with each other-which never happens! So actually the MDCA project is actually bringing the communities closer to each other now.

(interview, Macassar resident)

\section{Barriers to successful comanagement}

The significant number of barriers to comanagement identified required the construction of a larger number of broader themes. Firstly, many from the conservation staff feel that the formative stages of the comanagement process were incorrectly managed (Theme B1), and thus presented persistent problems in contemporary arrangements. Some feel that comanagement implementation was "imposed from above" by the University of Cape Town and the City of Cape Town, the correct community structures failed to be included, land ownership issues were not resolved, and community expectations regarding comanagement processes and intended benefits were inappropriately managed: 
I mean the community had an expectation that out of the planning things would happen, and it's when we come to the implementation that we fall flat as a public sector. Then there's all kinds of excuses, and maybe good reasons, but it doesn'tmatter - the result is what the communities are looking for. We failed the test . . . but we need to also look at what one learned out of it, and the big thing is: don't create an expectation that you can't deliver.

(interview, City of Cape Town Planning)

Whilst the University of Cape Town and planning staff feel the large-scale funds granted to MDCA presented important community development opportunities, many conservation staff feel there are ethical issues involved in bringing large sums of money into "previously disadvantaged" communities:

Now, when you go into a marginalized community you don't say 'hello, we have money! What do you want us to do?!' That is a bit of a problem because it means that anyone that becomes involved is there because there's funding; then when the limited funding dries out no one is interested. So they use money now to get people involved, to get people excited.

(interview, Cape Flats Nature).

Some feel the consequence of these formative stages is that the concepts, goals, processes, and outcomes of comanagement are not properly understood by communities. University of Cape Town staff, however, feel these perceptions regarding these formative stages are misconceptions held by those newer, and thus less informed, comanagement participants, who were not present at the formative stages of comanagement, during which lengthy and inclusive processes of engagement were conducted, and shared projects and goals were reached between comanagement partners.

Another barrier that was identified revolved around issues of leadership, decision-making, and power-sharing (Theme B2). Quite consistently interviewees identified historically poor leadership in the Management Committee throughout its decade-long history. Some feel this issue was generated by internal Committee politics, while others feel responsibility lies with the comanagement instigators and implementers, the City of Cape Town, and the University of Cape Town:

The MDCA didn't just come up from nowhere... There was an MoU or agreement between different institutions-and where are those institutions in terms of advising that leadership? [] It just seems like the MDCA was created and then they took a backseat . . . Those institutional partners, they should still be there to advise them and, you know, lead them towards the right direction.

(interview, Cape Flats Nature).
Some conservation and University of Cape Town staff feel the community members of the Management Committee fail to "take charge" of MDCA, and instead they incorrectly perceive that government and University of Cape Town staff are "in charge" of the process. Furthermore, many feel clear decisionmaking processes or structures are not set in place for the Management Committee, meaning that issues are repeatedly deliberated without resolution. The University of Cape Town feels that without a formalized, functioning comanagement agreement the process lacks legitimacy:

So yeah, in terms of the co-management with us, with the City, with the [community] groups, my feeling is that it's very tenuous; there is no arrangement at the moment .... Unless you have management involved, you're powerless. So I mean, you've got to have the government coming to the party and sitting down and saying ' $\mathrm{OK}$, we support the initiative: these are the responsibilities we as the government will take on; what responsibilities will you as the community take on?'. . But I mean, we [are] sort of light years away from that because as far as I see, from the moment that the City said 'we don't support this'having supported it all along-there is no partnership.

(interview, University of Cape Town).

At the same time, many feel the balance of power is tipped in favor of the authorities, meaning that community voices are not heard in decision-making:

And you know what is [the communities'] frustration? Their frustration was they're like a little puppet, that didn't take real decisions and that didn't have anything to show, meaning that they really desperately needed action and intervention in the area ... and I think there is where the problem lies. Um, I think the public authorities needed to show more oomph, more guts, and if they were pulling together I think ... they would've made more impact. (interview, City of Cape Town Planning)

A third theme relates to representation and self-interest (Theme B3). Many respondents felt that MDCA was not, at the time of the interviews, representative of all interested stakeholders, such as industry and business (e.g., the sandmining industry), and all three tiers of government (local, provincial, national). City of Cape Town conservation staff felt MDCA is too narrowly focused on the initial proposed projects, thus failing to include other nearby communities and large swathes of the dunes. Meanwhile, symbolic perhaps of some of the historical racial tensions and difficulties of inclusion and representation that underlie the comanagement process, some Macassar residents feel MDCA has been too focused on the Khayelitsha community: 
Although it's named Macassar Dunes Comanagement, it's focused on the Khayelitsha side, and it's where a lot of things have gone wrong . . . (interview, Macassar resident).

Government staff felt it was difficult to know who 'speaks' for communities, and whom individuals are representing when they engage with the MDCA:

\begin{abstract}
One needs to also be wary about the different groups that participate in those discussions, because certainly in the very first few meetings that I participated in for the first year and a half... there was a lot of sand-mining operators that came to those meetings and they would use it to lobby their interest. And then there'd be community groups, there'd be heritage groups, all sorts of different lobbies, and trying to get to the nib of who those groups are and what their interest is, is also something that needs to be understood.

(interview, Planning).
\end{abstract}

Further, some government and community members feel that rather than representing community interests the Management Committee is, unacceptably, being used for self-interest by community members, to gain personal employment or opportunities:

Let's say we are doing alien clearing: a person from the executive will look for his or her company to do that [contract] . . . So now each and every one now is looking for that "slice of bread". So that is what is gonna break the MDCA down.

(interview, Khayelitsha)

A fourth barrier surrounds what we broadly refer to as capacities (Theme B4). Many interviewees feel that, due to the disjointed process, there is a persistent lack of sustained capacity and skills within the Management Committee to effectively organize and run MDCA, and without sustained support from conservation and University of Cape Town staff, MDCA would essentially collapse:

There's been this capacity building that is happening as far back as 1999, but it does not produce any capacity... since there was training, it should have produced people who have management skills, who can manage finances, who can manage the organization-we don't seem to have those people . . . Simple bookkeeping, simple minutes taking, simple leading the organ is at ion in a particular direction-it's not happening.

(interview, University of Cape Town)

Concerns also exist regarding the capacity of government actors to effectively engage with MDCA and nearby communities, and this capacity-deficit is acknowledged by government actors themselves in terms of community development understanding and expertise:

There needs to be a sense, even in an informal settlement where the poorest of poor live, of the interdependence and the longer term view that one needs to have of your interaction with nature; it's as simple as that [but] it's not an issue that comes naturally if you're thinking about where you're going to get your next plate of food . . . On paper [comanagement] looks different from implementation, and it's because there's just a lack of understanding between the choices or the lack of choices these people [informal settlers] have got.

(interview, City of Cape Town Planning)

Furthermore, many community members feel it is unfair and obstructive that the Management Committee, through the University of Cape Town, lacks adequate access to MDCA's funds and resources (Theme B5), and are consequently forced to spend personal money to keep up MDCA's work:

We've done so many things out of our own pockets and nobody sees it, but we're driving things for the community... My poor vehicle, his poor vehicle, is already broken down for running up and down for community things, and we're not getting paid for it. There's a lot of things-I mean you don't get a salary for doing these things, we're doing these things on a voluntary basis, but we've found that it is not possible to do it anymore.

(interview, Macassar resident)

Meanwhile, some conservation staff feel the University of Cape Town's funding of MDCA serves to unethically and ultimately unsustainably "prop up" a community organization:

I think the wrong thing about [University of Cape Town] is that they were trying to prop up an organization ... They've been getting some funding for their office, and partly subsidizing them and that ... and it's just really, really, really wrong. I dunno; it's just doesn't kind of work, you know, because it's not sustainable . . . They're actually trying to prop them up with money, you know, [which the MDCA] need to be able to get themselves.

(interview, City of Cape Town Conservation)

A central theme, already evident in the historical reconstruction of the comanagement process, is the perception of discontinuities in the process and changing participants in MDCA (Theme B6). Some Cape Flats Nature and community participants feel the high turnover of City of Cape Town and the University of Cape Town staff has been problematic for process continuity. Erratic MDCA 
membership in general is perceived as a significant barrier, each time requiring a revitalization process, and resulting in lost capacity and the repeated revisiting of issues and ideas:

It just seems to me that every time we have a new Committee there's new personalities involved, new ideas. And you would prefer to go forward but you end up going two steps, three steps back. . . And that's where it's at at the moment again.

(interview, City of Cape Town Conservation).

Crucially, interviewees from all groups recognize as problematic the City of Cape Town's changed stance from support to objection in regards to MDCA's project proposals, and in the failure of all parties to effectively communicate and reach consensus on viable alternatives:

The City said 'we don't have any problem with the eco-trails, but no structures will be built on-site'. So, over the years ... the project has been on the same spot, it has been arguing and discussing with the City whether they can build a structure or not. (interview, University of Cape Town)

Also identified are three related issues of perceptions of motivation and trust, and commitment to comanagement (Theme B7). In general, the long and stilted processes of deliberation, persistent issues, and lack of results have caused many people to become de-motivated and lose interest in the MDCA. Some feel motivation is only present when there is funding available, dropping off when there is none. Others feel motivation was severely quashed when the City of Cape Town rejected the MDCA's project plans. Moreover, some feel the City of Cape Town and/or University of Cape Town are not committed in the long term to making comanagement sustainable. At the same time, some government interviewees recognize that their own unwillingness to fully participate is representative of MDCA's historical failure and their distrust that the organization can run sustainably. Given perceived low organizational capacities, the University of Cape Town does not trust the Management Committee members to carry out their functions and responsibilities. This concern is spurred by the University of Cape Town's accountability to funding bodies to spend the granted funds as they were intended:

Now there's this tension between [University of Cape Town] and the Management Committee on the ground. [The Committee] want to manage the funds [but University of Cape Town] says 'no, we need to account for these funds'. And even myself, if I was [University of Cape Town] I wouldn't give them the money. In my mind there's something that says 'they can't manage it'. I'm not sure why. It's not something intelligent-I'm from the community, I was born and grew up in the townships - I can tell you that they cannot do it. I'm not sure what's lacking, but what
I'm saying is I'm not sure what could be done to enhance people's capacity, to be sure that those who are involved in the comanagement have the capacity, have the know-how of running an organization... Now, it remains the City that's still managing that area all by itself.

(interview, University of Cape Town).

\section{DISCUSSION}

The range of perceptions evident within this analysis demonstrates with all clarity that the practice of comanagement at the rapidly growing Cape Town "urban fringe" presents no easy task. And certainly, the perceptions confirm that comanagement is not just about managing natural resources, but it is also fundamentally about managing social relationships (Goetze 2005). Yet when significant differences are evident in what constitutes "everyday life" between those engaged in comanagement, the management of such relationships is infused with significant power differentials, and thus is potentially highly problematic. While some comanagement participants live in informal shack dwellings that perhaps lack proper sewerage and water access, others are more securely housed and employed, and tasked with the clear objective of protecting biodiversity. Nonetheless, this apparently incongruous situation is bound to become more frequent as natural resource management engages the "urban fringes" in cities of the Global South. Before moving to a more case-based discussion, Macassar Dunes seems to provide some initial hints of new dimensions of comanagement practice that will require more research across various case studies to be able to explore these dimensions in the context of natural resource management theory-making.

One such dimension is the intersection of comanagement and urbanization and poverty/informality. In this case study this intersection shaped perceptions of the comanagement process, as well as the actual framing of the comanagement arrangements. While conservation biologists feared that the urban poor of eNkanini would "invade" the protected area, the long-term community of Macassar felt that the comanagement arrangement was too focused on the informal settlers of eNkanini. The political volatility and relative ease by which informal settlers can move their dwellings, or build new dwellings-using corrugated metal and recycled materialappears as a crucial dimension that intersperses amongst several identified bridges and barriers. This situation demonstrates the complex and relational nature of power dynamics and stakeholder agency within the comanagement process. This dimension of informality is a situation that is likely general across many city spaces in the Global South.

A second related dimension is how poverty and equity issues intersect with spatial and economic development desires and trajectories. This dimension relates to what local and national governments or NGOs can possibly promise as material or 
economic benefits when they initiate comanagement arrangements. Although rural studies often deal with poverty, it seems to be the concentration of poverty in this urban case study that presents a new dimension requiring further research in the context of urban comanagement regimes. The question is not so much whether "locals" or "indigenous people" should be able to extract resources from the protected area, but whether or not the area is to continue to exist de facto as a protected area at all. Few studies of comanagement have anything to say about how these dimensions intersect and how to analyze them, let alone how to handle them in practice. However in order to begin examining them we propose to analyze a subset of them through the lenses of "implementation", "legitimacy", and comanagement as "process".

\section{Comanagement implementation, legitimacy, and process}

The formative stages of the comanagement process represent a fundamental comanagement barrier for some interviewees, and have implications in the contemporary setting in relation to who should now "take responsibility" for the MDCA's functioning. Initial implementation of comanagement at Macassar Dunes can be viewed as biased towards a more "topdown approach", initiated and implemented as it was by government staff and researchers. This stands in contrast to Chuenpagdee and Jentoft's (2007:659) understanding that, ideally, comanagement should "start from a heartfelt problem at the community level and not from some conceptual problems perceived at a higher level". The educational (and top-down) activities have worked to inform township and eNkanini residents that the dunes can protect them from prevailing winds, and have thus worked to provisionally halt further spreading of the settlement. Importantly, these activities are collectively viewed by interviewees as bridges to comanagement. This process might be one way of starting to embed the dunes and their values in "everyday life" by showing their utility value, and it is also reflective of a topdown shaping of values and problems.

At the same time, the issues regarding comanagement implementation are rather complex and nuanced in the stakeholder perceptions. For one, the situation at Macassar Dunes denotes a complex interplay between the top-down and bottom-up approaches, because the perceptions herein indicate that impetus to maintain the comanagement process now comes largely from the "bottom-up", in the form of local community representatives of Macassar and Khayelitsha. Secondly, the perceptions of improper comanagement implementation and facilitation are disputed by different interviewees. The University of Cape Town, for example, understands they have taken time to understand the local contextual situation (Chuenpagdee and Jentoft 2007) and moreover sought to involve all relevant stakeholders through long and intensive processes of community engagement and extensive capacity building, and that this fact has been lost through the course of the stilted process and changing comanagement membership. Furthermore, the granted comanagement funds are perceived by many stakeholders (and, importantly, by the community members) as representative of real potential for community development and comanagement collaboration at Macassar Dunes. The perception exists that consequential to these formative stages the local communities do not understand the concepts, goals, processes, and outcomes of comanagement. However, it rather appears as of 2009 that comanagement partners have failed to reach shared understandings of what are the terms of reference for the comanagement arrangements (Cundill 2010), or what Borrini-Feyerabend et al. (2001:41) describe as "a common vision of a desired future".

What these issues speak to is the concept of comanagement legitimacy, which Kofinas' (2005) asserts is essential for achieving stakeholder consensus and then for transforming that consensus into action within the group. The failure of MDCA to reach agreement on alternative project plans is testament to this need for a shared sense of legitimacy. At the time of this study, perceptions differed regarding the legitimacy of the arrangements, and thus decision-making processes and tangible comanagement outcomes have proven largely untenable. The University of Cape Town, on the one hand, feels that without formal government acceptance of comanagement arrangements "there is no comanagement", and both conservation and University of Cape Town staff feel that MDCA is not functioning as an organization. On the other hand the long-existing arrangements, the available project funding, and the constitution developed between the University of Cape Town and communities in 2003 were expressions of legitimate arrangements for many community members, in particular for those who had been involved for several years-some since the comanagement's inception.

Perceptions of legitimacy are also dynamic and liable to change, and thus require cultivation if the legitimacy perception is to persist (Kofinas 2005). Shifting perceptions of the legitimacy of the arrangements at Macassar Dunes are perceptible through the discontinuities in process and participation. For example, there is community awareness that these formal arrangements lack specific mechanisms for decision-making processes, and frustration is present that comanagement faces seemingly unnecessary barriers posed by authorities, such as hindered access to financial and organizational resources and lack of trust and commitment. It furthermore appears these legitimacy concerns and resultant process discontinuities are manifest through motivational loss for comanagement participation at several times, and thus the repeated need for process revitalizations. Castro and Nielsen (2001:237) have noted that in the frame of comanagement " [v] iable and productive networks will not happen without an adequate investment of time, financial resources, and social capital". It appears that consideration of these issues is a central 
priority at Macassar Dunes, because at the most fundamental level the various stakeholder groups have differentiated access and ability to engage with comanagement on a processual level.

Legitimacy issues also come into focus because the University of Cape Town and the government organizations are waiting for the community members of the MDCA to act "independently" of their input, rather than seeing themselves as crucial actors in a sustained partnership effort between all comanagement partners. At a fundamental level these legitimacy issues speak to the importance of recognizing comanagement as process, involving extensive deliberation, negotiation, and the evolution of agreements (Berkes 2009). Armitage et al. (2009) have noted that some arrangements may take over a decade to "mature" into effective governance arrangements, based on trust and social capital, open communication, and commitment to repeated stakeholder interaction. Issues of lack of trust and commitment to the comanagement process, and failure to communicate effectively to make decisions at Macassar Dunes, signify the process had not at the time of the study matured into effective governance arrangements, despite the decadal time frame. Indeed, this is most fundamentally represented by the perceived barriers of poor leadership, unequal power-sharing, and poor decision-making processes. Recognition of comanagement as processual highlights further how powersharing comes as a result of the process, rather than just because it is an initial expected outcome (Carlsson and Berkes 2005).

On the other hand, many of the bridges suggest the successful building of social capital between the Macassar and Khayelitsha communities, and between government institutions and communities. Together with educational and value-change processes, we suggest it is in these areas where the comanagement arrangement's strengths lie. However, these successes are simultaneously perceived as tenuous, and further exploration is required on why these perceptions are unstable.

\section{Opening possibility spaces}

Thus far our study and analysis are couched within the conceptual apparatus of contemporary natural resource management theories, and comanagement theory in particular. This analysis of the bridges and barriers to comanagement of Macassar Dunes through comanagement theory has provided important insights to questions of conflict and historical and processual issues encountered within the arrangements to 2009. However, much remains to be understood abut the complex interplay between the bridges and barriers, the stakeholders, and indeed the place-Macassar Dunes-itself, which, after all, has motivated the interviewees to act on its behalf in the comanagement arrangements. Given there is little research on a phenomenon that will most certainly increase- the management of biodiversity and ecological values at the fringes of rapidly growing cities in the Global South-one might ask if conventional natural resource management discourse is "up to the task" of reflecting on this complex interplay, or rather if new methods and theories need to be developed for and from the places with which they seek to interact. We here allude that a broader research agenda is necessary to push theory on natural resource management and comanagement to include the complex spaces of the urban fringes of the Global South. (And, indeed, to the many (often invisible) urban fringes and complex spaces of the Global North.)

Consideration of how Macassar Dunes becomes "the fringe" through the constitution of its counterpart, "the center" provides an important entry point for reflecting on why such theoretical innovation is required, and indeed, on the power relations manifest in natural resource management discourse, theory, and practice. With offices at the world-renowned Kirstenbosch Botanical Garden, and speaking from the discursive and geographical "center", the South African National Biodiversity Institute biologists Rebelo and colleagues (2011) summed up the threats facing Cape Town's highly biodiverse strandveld vegetation areas, which are located at the urban fringe of the densely populated and largely impoverished Cape Flats (of which Macassar Dunes belongs). In contrast to the locations of high biodiversity, fynbos vegetation found in the formerly "white", established, and better-resourced suburbs of Cape Town, "strandveld tends to have large-scale dumping of industrial and builders' rubble, extensive removal of medicinal plants and firewood, illegal hunting with dog packs, and largely disinterested communities who either see the reserves as "bush of evil" due to drug-, rape-, and safety issues, and who are antagonistic to conservation officers, or where interest groups exist, these tend to be community-focused and under-resourced" (Rebelo et al. 2011: 30). In the context of urban nature conservation, as defined from "the center", the "urban fringe" becomes framed as problematic and threatening, and without ability to speak for itself.

Consequently, if the starting point for comanagement at the "urban fringe" is defined by "the center", then the core values around which comanagement is organized, implemented, and negotiated, and on which basis "educational activities" are premised and conflicts "resolved", these will be defined by the core values of "the center". This Foucauldian notion of how power relations define what is to be considered of value - and indeed, how reality is to be conceived - can work to silence alternative voices at "the fringe" (see Foucault 1980; Swyngedouw 2009). If comanagement is a process by which to "democratise decision-making" (Armitage et al. 2007), and which ought not partake within a "deep-colonizing" project (Rose 1999; see Howitt and Suchet-Pearson 2006) then this insight of how "the center" might seek to control the meanings 
and values at "the fringe" demands, we believe, different methods and theories for research and understanding.

Based on our interpretation of the interview data, we recognize "the fringe" as a concept that is both relational and subjective, and, furthermore, one that is layered with historical assumptions about "the center" and its hierarchical gaze and distanced relativity to the "othered" fringe. In aiming to problematize this framing of the fringe, and to better understand the social-ecological dynamics that necessarily influence any attempt at comanagement, future research will need to draw on scholarly work that seeks to reframe the fringe and its conventional associations. For example, geographical work on spaces of the urban fringe that has highlighted the tenuousness of dichotomous urban/rural understandings (see Lerner and Eakin 2011) provides important reframing potentialities. It is at these "fringe" locations that conventional associations of "the urban" and "the rural", and expected relationships between "people and nature" and "people and the city", are challenged. Indeed, the ways urban green areas are purportedly used and conceived in Cape Town's urban fringe seemingly challenge Rebelo et al.'s (2011) normative associations of how urban protected areas should be used and valued.

Further, Howitt (2001:242) seeks to recontextualize colonial and neocolonial "geographical imaginaries" of "the borderlands", "edges", "frontiers" away from spaces of fear, and otherness to "liminal spaces" of much diversity, in which the possibility spaces for constructive exchange, interaction, and co-existence are opened, rather than predefined in advance by those in the "center". Lloyd et al. (2010: 701) also show how the use of personal and culturally embedded stories "redefine the border as a dynamic and active space and as a site of complex encounters". To engage, or indeed construct, these possibility spaces, future research will need to strive to set existing comanagement theory in communication with cultural geographical theory, and also strive to help to open possibility spaces among academics on how to recombine different bodies of work to construct a theory for the "urban fringes" of the Global South. The aim must be to generate empirical data and theory that are sensitive to the ways of knowing and valuing "fringe" places of those living at the "fringe", and in so doing, attending to the diverse array of human-environment relationships and the range of understandings and ways of knowing ecological complexity. We believe this will provide important insights to comanagement at Macassar Dunes, and to the bridges and barriers perceived by MDCA stakeholders. Such insights will also be important for considering comanagement as theory and practice in the possibility space of "substantial promise" and "source of conflict" (Castro and Nielson 2001).

\section{CONCLUSION}

We hope to have contributed here to building a body of knowledge about a specific urban protected area comanagement arrangement, in the context of a rapidly urbanizing city in the Global South. Our empirical account aimed to give some voice to those engaged and involved in such processes on-the-ground. Through concentrating on perceived successes and failures in the process (Berkes 1997) we have explored the possibilities of both conflict and common ground in comanagement arrangements. Certainly, analysis of these bridges and barriers through the lens of comanagement theory has provided important understandings regarding the processes of comanagement, and the attendant capacities and limitations of stakeholders to engage with these.

While we primarily focused on the potentialities for conflict and common ground in the specific comanagement arrangements at Macassar Dunes near Cape Town, South Africa, we have also pointed out new research directions for a phenomenon that is bound to increase: namely, the management of biodiversity and ecological values at the fringes of rapidly growing cities in the Global South. Novel dimensions that seem to influence comanagement at the urban "fringe" include how the greater scale of poverty intersects with informality, and economic, social, and spatial development desires of differing stakeholder groups, and what material or economic benefits can be promised at the initiation of comanagement arrangements. We further made the case that the repertoire of research on comanagement processes at the urban fringe needs to expand to include theories and methods that can deal with issues of power and valuation processes. The inclusion of such can serve to recontextualize the "fringes" as possibility spaces for constructive interaction, through which diverse values and ways of knowing may be coconstructed through urban comanagement processes, rather than these being predefined and determined by those at "the center".

Responses to this article can be read online at: http://www.ecologyandsociety.org/voll7/iss3/art34/ responses/

\section{Acknowledgments:}

The first author is very grateful to the people of Macassar Dunes Co-Management Association for their kind assistance during the fieldwork research. Both authors are also most grateful for the comments from two anonymous referees, and for helpful suggestions from Dr. Sandie Suchet-Pearson, Macquarie University. This research was funded by the Formas Research Council through the Ways of Knowing Urban Ecology project, which aims to rethink urban ecology 
and natural resource management theory and practice (Dnr: 250-2010-1372). It was also funded jointly by the Swedish Research Council (VR) and South Africa's National Research Foundation (NRF) through the ESCAPE Project on the governance of urban ecosystem services in Cape Town city region (2007-4878-49975-4). The authors are most appreciative of the assistance and linkages that these projects facilitated. This paper is a product of the Urban Ecology CityLab which is part of the CityLab programme of the African Centre for Cities at the University of Cape Town. The African Centre for Cities' CityLab programme is funded through the Mistra Urban Futures network (which is funded by MistraThe Foundation for Strategic Environmental Research and by the Swedish International Development Cooperation Agency), the Provincial Government of the Western Cape (Department of Human Settlements), and the City of Cape Town.

\section{LITERATURE CITED}

Adams, W. M., D. Brockington, J. Dyson, and B. Vira. 2003. Viewpoint: managing tragedies: understanding conflict over common pool resources. Science 302(5652):1915-1916.

Alcamo, J., E. M. Bennett, et al., and Millennium Ecosystem Assessment. 2005. Ecosystems and human wellbeing: a framework for assessment. Island Press, Washington, D.C., USA.

Armitage, D., F. Berkes, and N. Doubleday, editors. 2007. Adaptive co-management: collaboration, learning and multilevel governance. University of British Columbia Press, Vancouver, British Columbia, Canada.

Armitage, D. R., R. Plummer, F. Berkes, R. I. Arthur, A. T. Charles, I. J. Davidson-Hunt, A. P. Diduck. 2009. Adaptive co-management for social-ecological complexity. Frontiers in Ecology and the Environment 7(2):95-102. http://dx.doi.or $\mathrm{g} / 10.1890 / 070089$

ATLAS.ti Scientific Software Development GmbH. 2009. ATLAS.ti. Version 6. Berlin, Germany. [online] URL: http://w ww.atlasti.com/index.html. http://dx.doi.org/10.1641/0006-3568 (2000)050[0477:RFA]2.0.CO;2

Base of Pyramid (BoP) Learning Lab-Southern Africa. 2011. The ultimate BoP laboratory-a socio-economic snapshot of Khayelitsha. Fact Sheet, August 2011. The BoP Learning Lab, University of Stellenbosch, Cape Town, South Africa. [online] URL: http://www.reciprocity.co.za/images/stories/attach/ Khayelitsha11.pdf.

Barthel, S., J. Colding, T. Elmqvist, and C. Folke. 2005. History and local management of a biodiversity-rich, urban cultural landscape. Ecology and Society 10(2):10. [online] URL: http://www.ecologyandsociety.org/vol10/iss2/art10/.
Berkes, F. 1997. New and not-so-new directions in the use of the commons: co-management. The Common Property Resource Digest 42(July):5-7.

Berkes, F. 2009. Evolution of co-management: Role of knowledge generation, bridging organisations and social learning. Journal of Environmental Management 90:16921702. http://dx.doi.org/10.1016/j.jenvman.2008.12.001

Bodenstein, J., and S. Rippon. 2006. Scoping report for Macassar Dunes Eco-Trails Project. Report No. 2/06/271. Environmental Evaluation Unit, University of Cape Town, Cape Town, South Africa.

Bolund, P., and S. Hunhammar. 1999. Ecosystem services in urban areas. Ecological Economics 29:293-301. http://dx.doi. org/10.1016/S0921-8009(99)00013-0

Borrini-Feyerabend, G., M. T. Farvar, J. C. Nguinguiri, and V. A. Ndangang. 2001. Co-management of natural resources: organising, negotiating and learning-by-doing. GTZ and IUCN, Kasparek Verlag, Heidelberg, Germany.

Boyatzis, R. 1998. Transforming qualitative information: thematic analysis and code development. Sage Publications, Thousand Oaks, California, USA.

Cape Flats Nature. 2010. Partnership sites. [online] URL: http://www.capeflatsnature.co.za/index.php?option= com content $\&$ view=article $\& i d=27 \&$ Itemid $=61$.

Carlsson, L., and F. Berkes. 2005. Co-management: concepts and methodological implications. Journal of Environmental Management 75:65-76. http://dx.doi.org/10.1016/j.jenvman.2 $\underline{004.11 .008}$

Castro, P. A., and E. Nielson. 2001. Indigenous people and co-management: implications for conflict management. Environmental Science and Policy 4(4/5):229-239. http://dx.d oi.org/10.1016/S1462-9011(01)00022-3

Chittenden Nicks de Villiers. 2001. Macassar Dunes management plan. Cape Town: City of Cape Town.

Chuenpagdee, R., and S. Jentoft. 2007. Step zero for fisheries co-management: what precedes implementation. Marine Policy 31:657-668. http://dx.doi.org/10.1016/j.marpol.2007.03.013

Cilliers, S. S. and S. J. Siebert. 2012. Urban ecology in Cape Town: South African comparisons and reflections. Ecology and Society 17(3):33. http://dx.doi.org/10.5751/ES-05146-170333

City of Cape Town. 2007. The identification and prioritisation of a biodiversity network for the City of Cape Town. [online] 
URL:http://www.capetown.gov.za/en/EnvironmentalResourc eManagement/publications/Documents/BioDNet Final Repo rt $022007 \quad 19122007172753$ 465.pdf.

Cook, I. R., and E. Swyngedouw. 2012. Cities, social cohesion and the environment: towards a future research agenda. Urban Studies 49(8). http://dx.doi.org/10.1177/0042098012444887

Cundill, G. 2010. Monitoring social learning processes in adaptive comanagement: three case studies from South Africa. Ecology and Society 15(3):28. [online] URL: http://www.eco logyandsociety.org/vol15/iss $3 /$ art28/.

Ernstson, H., and S. Sörlin. 2009. Weaving protective stories: connective practices to articulate holistic values in Stockholm National Urban Park. Environment and Planning A 41 (6):1460-1479. http://dx.doi.org/10.1068/a40349

Ernstson, H., S. E. van der Leeuw, C. L. Redman, D. J. Meffert, G. Davis, C. Alfsen, and T. Elmqvist. 2010. Urban transitions: on urban resilience and human-dominated ecosystems. Ambio 39(8):531-545. http://dx.doi.org/10.1007/s13280-010-0081-9

Ferketic, J. S., A. M. Latimer, and J. A. Silander. 2010. Conservation justice in metropolitan Cape Town: a study at the Macassar Dunes Conservation Area. Biological Conservation 143:1168-1174. http://dx.doi.org/10.1016/j.bio con.2010.02.024

Foley, A., and L. Grace. 2009. Water, weeds and autumn leaves: learning to be drier in the alpine region. Australian Journal of Adult Learning 49(3):451-471.

Foucault, M. 1980. Power/knowledge: selected interviews and other writings 1972-1977. Harvester Press, Hempsted, UK.

Goetze, T. C. 2005. Empowered co-management: towards power-sharing and indigenous rights in Clayoquot Sound, BC. Anthropologica 47(2):247-265.

Gustafson, P. 2001. Meanings of place: everyday experience and theoretical conceptualisations. Journal of Environmental Psychology 21:5-16. http://dx.doi.org/10.1006/jevp.2000.0185

Harvey, D. 1996. Justice, nature and the geography of difference. Blackwell Publishers, Oxford, UK.

Howitt, R. 2001. Frontiers, borders, edges: liminal challenges to the hegemony of exclusion. Australian Geographical Studies 39(1):233-245. http://dx.doi.org/10.1111/1467-8470.00142

Howitt, R., and S. Suchet-Pearson. 2006. Rethinking the building blocks: ontological pluralism and the idea of "management". Geografiska Annaler 88B(3):323-335. http:// dx.doi.org/10.1111/j.1468-0459.2006.00225.x
Izurieta, A., B. Sithole, N. Stacey, H. Hunter-xenie, B. Campbell, P. Donohoe, and J. Brown. 2011. Developing indicators for monitoring and evaluating joint management effectiveness in protected areas in the Northern Territory, Australia. Ecology and Society 16(3):9. [online] URL: http:// www.ecologyandsociety.org/vol16/iss3/art9/.

Kepe, T. 2008. Land claims and co-management of protected areas in South Africa: exploring the challenges. Environmental Management 41(3):311-321.

Kingwill, R., B. Cousins, T. Cousins, D. Hornby, L. Royston, and W. Smit. 2006. Mysteries and myths: De Soto, property and poverty in South Africa. IIED Gatekeeper Series 124. Natural Resources Group, International Institute for Environment and Development, London, UK.

Kofinas, G. P. 2005. Caribou hunters and researchers at the co-management interface: emergent dilemmas and the dynamics of legitimacy in power-sharing. Anthropologica 47 (2):179-196.

Langley, C. H. 2006. Macassar Dunes fauna study. Appendix 3 in Bodenstein, J. and S. Rippon, Scoping reportfor Macassar Dunes Eco-Trails Project, Report No. 2/06/271, Environmental Evaluation Unit, University of Cape Town, Cape Town, South Africa.

Lerner, A. M., and H. Eakin. 2011. An obsolete dichotomy? Rethinking the rural-urban interface in terms of food security and production in the global south. The Geographical Journal 177(4):311-320 http://dx.doi.org/10.1111/j.1475-4959.2010.00394. $\underline{\mathrm{x}}$

Lloyd, K., S. Suchet-Pearson, S. Wright, and L. Burarrwanga. 2010. Stories of crossings and connections from Bawaka, North East Arnhem Land, Australia. Social \& Cultural Geography 11(7):701-717. http://dx.doi.org/10.1080/146493 $\underline{65.2010 .508598}$

Magome H., and J. Murombedzi. 2003. Sharing South African national parks: community land and conservation in a democratic South Africa. Chapter 5 in W. M. Adams, and M. Mulligan, editors. Decolonising nature: strategies for conservation in a post-colonial era. Earthscan Publications, London, UK.

Miles, M. B., and A. M. Huberman. 1994. Qualitative data analysis: an expanded sourcebook. Sage Publications, Thousand Oaks, California, USA.

Niemelä, J., J. H. Breuste, G. Guntenspergen, N. E. McIntyre, T. Elmqvist, and P. James, editors. 2011. Urban ecology: patterns, processes, and applications. Oxford University Press, Oxford, UK. 
Rebelo, A. G., P. M. Holmes, C. Dorse, and J. Wood. 2011. Impacts of urbanization in a biodiversity hotspot: conservation challenges in metropolitan Cape Town. South African Journal of Botany 77:20-35 http://dx.doi.org/10.1016/j.sajb.2010.04.006

Reed, M. S., A. Graves, N. Dandy, H. Posthumus, K. Hubacek, J. Morris, C. Prell. 2009. Who's in and why? A typology of stakeholder analysis methods for natural resource management. Journal of Environmental Management 90 (5):1933-1949.

Rogan, R., M. O'Connor, and P. Horwitz. 2005. Nowhere to hide: awareness and perceptions of environmental change, and their influence on perceptions of place. Journal of Environmental Psychology 25(2):147-158.

Rose, D. 1999. Indigenous ecologies and an ethic of connection. Pages 175-187 in N. Low, editor. Global ethics and environment. Routledge, London, UK.

Skuse, A., and T. Cousins. 2007. Spaces of resistance: informal settlement, communication and community organisation in a Cape Town Township. Urban Studies 44(5/6):979-995. http: //dx.doi.org/10.1080/00420980701256021

Spaeder, J. J., and H. A. Feit. 2005. Co-management and indigenous communities: barriers and bridges to decentralized resource management: introduction. Anthropologica 47 (2):147-154. http://dx.doi.org/10.2307/25606232

Swyngedouw, E. 2009. The antinomies of the postpolitical city: in search of a democratic politics of environmental production. International Journal of Urban and Regional Research 33(3):601-620. http://dx.doi.org/10.1111/j.1468-24 27.2009.00859.x

Trzyna, T. 2007. Global urbanization and protected areas. California Institute of Public Affairs, Sacramento, California, USA.

United Nations Department of Economic and Social Affairs. 2012. World urbanization prospects: the 2011 revision, highlights. Population Division, New York, New York, USA. [online] URL: http://esa.un.org/unpd/wup/pdf/WUP2011 Hi ghlights.pdf.

United Nations Population Fund. 2007. State of world population 2007: unleashing the potential of urban growth. New York, New York, USA.

Watson, V. 2009. “The planned city sweeps the poor away...": urban planning and 21st century urbanization. Progress in Planning 72(3):151-193.

Wilkinson, P. 2004. Renegotiating local governance in a postapartheid city: the case of Cape Town. Urban Forum 15 (3):213-229. http://dx.doi.org/10.1007/s12132-004-0001-9
Willig, C. 2001. Introducing qualitative research in psychology: adventures in theory and method. Open University Press, Buckingham, UK.

World Parks Congress. 2003. WPC recommendation 25: comanagement of protected areas. World Parks Congress 2003, Durban, Benefits Beyond Boundaries, IUCN, The World Conservation Union. [online] URL: http://www.earthlore.ca/ clients/WPC/English/grfx/recommendations/PDFs/r25.pdf. 